\title{
JOURNAL
}

\section{FORMS OF HUMAN RIGHTS VIOLATIONS FACED BY PEOPLE WITH SCHIZOPHRENIA}

\author{
Rohimah \\ rohimah.fai@uia.a,.id
}

\begin{abstract}
Abstact :
On this occasion, we will present brief information about Schizophrenia as a form of mental disorder that lasts for the long term. Pe

ople with mental disorders are people who experience disturbances in thoughts, behaviors, and feelings manifested in the form of a set of symptoms and / or changes in meaningful behavior, and can cause suffering and obstacles in carrying out people's functions as humans. This is to differentiate from people with psychiatric problems are people who have physical, mental, social, growth and development problems, and / or quality of life so that they have the risk of experiencing mental disorders. This explanation was taken from Law No. 18 of 2014 concerning Mental Health.

Schizophrenia comes from Greek, schizein which means separate or broken and phren which means soul. Breaking out or mismatch between cognitive and behavioral effects. Schizophrenia is a functional psychosis with major disturbances in the thinking process and disharmony between thought processes, affect or emotion, will and psychomotor accompanied by distortion of reality, mainly due to delusions and hallucinations, divided associations so that appear incoherence, affect and emotional inadekuat, and psychomotor shows withdrawal, ambivalence and bizar behavior.
\end{abstract}

\section{Keywords: Schizophrenia, Mental Disorders, Mental Disorders.}

\section{A. INTRODUCTION}

Mental health conditions now can no longer be underestimated, mental health is as important as physical health and illness or other disabilities that arise in the body. In Indonesia the condition of mental health is still one of the sidelined issues. When we look at the data available, in terms of number, sufferers of mental disorders continue to increase. The 2013 basic health research data (Riskesdas) shows the prevalence of mental emotional disorders with symptoms of depression and anxiety at the age of 15 reaching 14 million people. This figure is equivalent to 6 percent of Indonesia's population while the prevalence of severe mental disorders such as schizophrenia reaches 400 thousand.

The phenomenon of severe mental disorders such as people with schizophrenia is increasingly gaining the attention of various parties, especially regarding the issue of fulfilling the right to health as mandated by the Indonesian Constitution that every person lives prosperously physically and mentally and receives health services. Schizophrenics have not 
been given a proper place to defend their rights as human beings and to restore themselves. Almost in all environments and received inhumane treatment.

Understanding of Schizophrenia is a clinical syndrome characterized by severe and diverse psychopathology, covering aspects of cognition, emotion, perception and behavior with mind disorders as the main symptoms. Onset is usually before the age of 25 years lasts a lifetime and can be suffered by all socio economic circles.

Fulfillment of the right to health for people with schizophrenia has a close relationship with human rights obligations. In Law Number 39 of 1999 concerning Human Rights is a set of rights inherent in the nature and existence of humans as God's creatures and is a gift that must be respected, upheld, and protected by the state, law, government, and everyone for the sake of honor and protection of human dignity.

Seeing the phenomena of Schizophrenia sufferers who apparently in their daily lives still have neglected human rights protection, we try to learn about the protection of human rights in schizophrenics in the Republic of Indonesia, especially in terms of health services.

\section{B. UNDERSTANDING OF SCIZOFRENIA}

In this paper, our group will briefly present information about Schizophrenia as a form of mental disorder that lasts for the long term. People with mental disorders are people who experience disturbances in thoughts, behaviors, and feelings manifested in the form of a set of symptoms and / or behavioral changes that are meaningful, and can cause suffering and obstacles in carrying out the functions of people as human beings. This is to differentiate from people with psychiatric problems are people who have physical, mental, social, growth and development, and / or quality of life problems so that they have the risk of experiencing mental disorders. This explanation was taken from Law No. 18 of 2014 concerning Mental Health.

Schizophrenia comes from Greek, schizein which means separate or broken and phren which means soul. Breaking out or mismatch between cognitive and behavioral effects. Schizophrenia is a functional psychosis with major disturbances in the thinking process and disharminalization between thought processes, affect or emotion, will and psychomotor accompanied by distortion of reality, especially due to delusions and hallucinations, divided associations so that appear incoherence, affect and emotional inadekuat, and psychomotor shows withdrawal, ambivalence and bizar behavior.

Schizophrenia is a disorder that lasts for at least 6 months and covers at least 1 month of active phase symptoms. Meanwhile schizophrenia disorders are characterized by positive symptoms (delusions and hallucinations), negative symptoms (apathy, withdrawal, decreased thinking power, and decreased affect), and cognitive disorders (memory, attention)

Based on the 10th International Statistical Classification of Diseases and Related Health Problems or abbreviated as ICD-10 and Comparison of Classification of Diagnosis for 
Mental Disorders III or abbreviated PPDGJ III, to establish a diagnosis of schizophrenia must have at least one of the following clear symptoms. Listed below are the symptoms that appear in schizophrenics:

\section{Thought Echo}

The contents of his own thoughts that echo and repeat in his head (not hard) and the contents of the mind repeat, although the contents are the same, but the quality is different.

\section{Thought Insertion or Withdrawal}

The contents of foreign thoughts from outside enter ked ala his mind (insertion) or the contents of his mind are taken out by something from outside himself (withdrwal).

\section{Thought Broadcasting}

The contents of his mind spread out so that other people or the public found out.

\section{Delution of Control}

Understanding about itself is controlled by a certain force from the outside.

\section{Delution of Influence}

His understanding of himself is influenced by certain powers from outside.

\section{Delution of Passivity}

Understanding about himself is helpless and resigned to outside forces.

\section{Delution of Perception}

Unusual sensory experience that is meaningful is very distinctive for him, usually mystical or miraculous.

\section{Delution of Auditors}

Hallucinations that comment continuously and so forth.

By looking at the symptoms of schizophrenia above, we can see how exactly a schizophrenic person thinks, so that we can understand the extent to which human rights law in schizophrenics can be applied. 


\section{EFFORTS FOR FULFILLING THE HEALTH OF HEALTH FOR PEOPLE WITH THEMS}

Human rights if we review Article 9 of Law Number 39 Year

1999 concerning Human Rights is as follows:

1) Everyone has the right to live, maintain life and improve their level his life.

2) Everyone has the right to live in peace, security, peace, happiness, prosperity and birth inner.

3) Everyone has the right to a good and healthy environment.

In Law Number 39 of 1999 concerning Human Rights, as stated in Article 1, Human Rights are defined as a set of rights inherent in the nature and existence of human beings as God's creatures and are His gifts that must be respected, upheld and protected by the state, law, government, and everyone for the sake of honor and protection of human dignity.

Human rights are universal, the recognition that for all and every person inheres the dignity and dignity of humanity that is not determined by race background, color, religion, sex, political beliefs, and historical background. It also means that the international community has a universal responsibility to act to correct violations of human rights that occur. Human Rights are human rights that are very basic and cannot be intervened by humans outside of themselves or by any group or institution to eliminate them. Human rights have essentially existed since a man was in his mother's womb until he was born, and throughout his life until the time he died.

In Article 1 of Law Number 39 Year 1999 concerning Human Rights, it is defined as a set of rights inherent in the nature and existence of human beings as God's creatures and is His gift that must be respected, upheld and protected by the state, the law, the government, and everyone for the sake of honor and protection of human dignity. In general, perspectives on Human Rights consist of:

a. Human Rights is a thing that applies universally (universality). Although there are various moral and ethical values that are spread throughout the world, basically human rights cannot change.

b. Human Rights prioritizes respect for human dignity (human dignity).

c. Human Rights acknowledge as stated in Article 1 of the General Declaration of Human Rights that every human being is born free and equal in his dignity. All humans have an equal position (equity).

d. Human rights do not recognize differences based on race, color, sex, language, religion, politics or other views, nationality, ownership, birth status or other (nondiscrimination).

e. Human Rights inherently attached to each individual cannot be taken away, released, or transferred (inalienability). 
f. Human rights, whether civil, political, economic, social and cultural, are all inherent in human dignity (indivisibility). Waiver of one right will result in the waiver of another right.

g. Human Rights are interrelated and dependent on each other (interrelated and interdependence).

h. Human Rights are more the responsibility of the state to make it happen. States and other obligations must be held accountable for complying with and fulfilling human rights.

\section{A. PRINCIPLES OF HUMAN RIGHTS FOR PEOPLE WITH THEMS}

Human Rights as basic rights attached to human beings are universal and enduring, so they must be protected, respected, maintained and must not be ignored, reduced, or taken by anyone, except by Law or Court Decision. The Human Rights Program aims to achieve equality in human rights and support in this case for people with schizophrenia.

With the fulfillment of the right to health, efforts are made so that people with schizophrenia are no longer discriminated against by the general public who think that people with schizophrenia are people affected by the curse, but also so that the public is more open to see that people with schizophrenia are also part of the community who have the same rights as other communities without exception. Schizophrenics also need the same role as other healthy people so they do not feel excluded from the surrounding community, and feel they are still able to provide benefits to the surrounding environment. Understanding Human Rights as Rights according to law has a broader understanding, not only natural rights or moral rights, but also includes rights according to law made by the competent authority in the country.

What is meant by rights in discussions on human rights is defined as an environment of circumstances or areas of freedom of action where the government does not impose restrictions, so it allows individuals or individuals to choose for themselves. Therefore, the right implies limiting the sovereign power of the government.

The subject of human rights is humans as individuals and groups as rights holders and the state as duty bearers for the implementation of human rights. Rights holders are people as individuals and groups who have rights, which must be respected, protected, and fulfilled by the state. Rights holders can be specified in various target groups, namely: women, children, adolescents, indigenous peoples, the elderly, physically disabled, mentally disabled, prisoners / detainees, internally displaced persons, migrant workers, private sector workers, informal sector workers, communities urban poor, farmers, fishermen, HIV / AIDS sufferers, minority groups, state apparatus, victims of human rights violations, witnesses and victims of human rights violations, users of public transportation services, and others. The party responsible for implementing human rights is the state.

Manfred Nowak states there are four basic human rights principles, namely: 
1. Universal (Universality)

2. Not sharing (Indivisibility)

3. Interdependent

4. Interrelated

Besides Manfred Nowak, Rhona K.M, Smith also mentioned that other human rights principles are:

1. Equality

2. Non-Discrimination

3. Human Dignity

The Indonesian state also emphasizes the principle of implementing human rights protection, that is, human rights are the state's responsibility.

In this context, the state promises to respect, protect and fulfill human rights. In relation to the state as an obligation holder, the provisions of human rights law affirm the following matters:

- First:

Placing the state as a responsibility bearer (duty bearer) who must fulfill his obligations in the implementation of human rights, both nationally and internationally, while individuals and community groups are rights holders.

\section{- Second:}

The state in the provisions of human rights law has no rights. The state only bears the obligation and responsibility to fulfill the rights of its citizens, both individuals and groups, which are guaranteed in international human rights instruments.

- Third:

If the state does not want or has no desire to fulfill its obligations and responsibilities, it is at this time that the country can be said to have violated human rights or international law. If the violation is not accounted by the state then that responsibility will be taken over by the international community.

The obligations and responsibilities of the state in the framework of a Human Rightsbased approach can be seen in three forms:

1. Respect: It is the state's obligation not to interfere in regulating its citizens when exercising their rights. In this case, the state has an obligation not to take actions that will hamper the fulfillment of all human rights.

2. Protect: It is the state's obligation to act actively for its citizens. States to act actively to guarantee the protection of the rights of their citizens and the state is obliged to take measures to prevent violations of all human rights by third parties. 
3. Fulfill: It is the obligation and responsibility of the state to act actively so that the rights of its citizens are fulfilled. The state is obliged to take legislative, administrative, legal, budgetary, and other measures to fully realize human rights.

Of the three forms of state obligations and responsibilities, each element contains an obligation to act (obligation to conduct) that requires the state to take certain steps to carry out the fulfillment of a right, and the obligation to impact (obligation to result ) i.e. requires countries to achieve certain targets to meet measurable substantive standards. In addition to the three main forms of obligation in the implementation of human rights, the state also has the obligation to take steps (to take step) to guarantee, to ensure, to recognize, to try ( to undertake) and to promote / promote (human rights). Efforts to fulfill the right to health can be done in various ways including prevention and healing. Prevention efforts include creating decent conditions for good health ensuring the availability of food and employment, good housing, and a healthy environment. While the healing effort is done by providing optimal health services. Health services include aspects of social security for health, adequate health facilities, qualified medical personnel, and financing of services that are affordable to the community.

\section{B. FORM OF VIOLATION OF HUMAN RIGHTS THAT ARE FACED WITH SCIZOFRENIA PERSONS}

There are a number of schizophrenics who roam the streets of the protocol. They become homeless without anyone paying attention to their health condition. It is not known exactly how many of them are homeless. This phenomenon of psychotic homelessness needs to be taken seriously considering that their distance is not the object of physical and nonphysical violence. In some areas, local governments often carry out urban cleansing programs by treating homeless people as unworthy people to put them in a place to live. The party that often does the cleaning is Satpol PP. There are still many parties who consider schizophrenia difficult to recover. This assumption arises because there is not much information about those who have recovered and returned to their families, communities, and activities like other community members.

The community's understanding of schizophrenia is still low and considers schizophrenic patients to be a social rubbish causing many human rights violations, especially the right to get good health services, to be ignored.

\section{F. CASE REVIEW}

The patient, a woman, aged 26 years, came to X Hospital, accompanied by adoptive parents. The adoptive parents consulted the obstetrician and obstetrician to ask the doctor at RS $X$ to abort the contents of the patient on the grounds that the patient was not known to be pregnant with anyone (suspected of having had a forced sexual relationship) and the patient was schizophrenic. The adoptive parents of the patient feel, the patient is not fit to 
be a mother because the patient is a very severe psychiatric disorder patient and the patient will not be able to take care of her baby later.

From this case review, it can be seen that the patient's parents do not fully understand about schizophrenia. Schizophrenics are categorized as a fairly severe psychiatric disorder, but schizophrenia can be controlled for abnormal behavior by using drugs and exercises that support the daily life of schizophrenics.

The act of forcing an abortion by force on schizophrenics in addition to violating Law Number 39 of 1999 concerning Human Rights, In addition, the abortion of pregnancy in schizophrenics can also be said to be a violation when seen from the Law Number 36 of 2009 concerning Health which in :

1. Article 4 : Everyone has the right to health.

2. Article 75 Paragraph 1 : Every person is prohibited from having an abortion.

Thus, a woman with schizophrenia has the same rights as a normal woman in terms of reproduction and education, as long as the patient is in regular control with psychiatry and follows counseling guidance with experts who have competence in the management of schizophrenia therapy.

\section{COVER}

\section{A. CONCLUSION}

1. Schizophrenia is a psychiatric disease that often sufferers get less attention from many parties. This is due to people's concern about the disease, so that the rights to health for people with schizophrenia are often neglected and even lead to violations of human rights as a result of inclusion and forms of violence experienced by people with schizophrenia. Demonstrate that efforts to fulfill the right to health for schizophrenics have not been carried out with priority in terms of availability, accessibility, protection and fulfillment of basic mental health. Therefore the state is obliged to provide mental health services which are carried out in stages, directed and integrated. In an effort to fulfill the right to health, there are obstacles or problems in the effort to fulfill the right to 100 health for people with schizophrenia.

2. In relation to human rights violations for schizophrenics who die in rehabilitation and street care centers as psychotic homeless people, this indicates an element of neglect by government officials resulting in physical / non-physical violence and abuse suffered by schizophrenics. Including acts of sexual violence also occurs in women with schizophrenia.

\section{B. SUGGESTIONS}


Persons with schizophrenia / People with mental disorders are not physical illnesses that cause death effects, but early detection of symptoms of mental disorders is very necessary to be socialized to the wider community so that there is no delay in handling in the initial phase that can be cured. It also needs community empowerment to increase knowledge about what and how about mental disorders and emotional disturbances at certain levels so as not to cause stigma against people with mental disorders who can be cured. Schizophrenic patients are also one of the human resources who can also empower their expertise as long as the schizophrenic patient is under the guidance of experts who have good competence in the management of schizophrenia therapy.

\section{REFERENCES}

\section{LITERATURE}

A.Widiada Gunakaya, Human Rights Law, Yogyakarta, Andi (IKAPI Member), 2017.

Eko Riyadi, Human Rights Law, International, Regional, Regional and National Perspectives, Depok, PT RajaGrafindo, 2017.

KOAS Study Guide Book, Mental Medicine, Udayana University Faculty of Medicine, Sanglah Central General Hospital, Department of Psychiatry.

\section{LEGISLATION}

Law of the Republic of Indonesia Number 39 of 1999 concerning Human Rights.

Republic of Indonesia Law 36/2009 concerning Health

Republic of Indonesia Act 18 of 2014 concerning Mental Health.

\section{ELECTRONIC MASS MEDIA}

https://dosenpsikologi.com/difference- mental disorders- and mental disorders https://ejournal.balitbanglam.go.id/index.php/kebintah/article/download/90/30 https://www.juke.kedempuanunila.ac.id $>$ article $>$ download $>$ pdf

\section{DAFTAR PUSTAKA}

\section{LITERATUR}

A.Widiada Gunakaya, Hukum Hak Asasi Manusia, Yogyakarta, Andi (Anggota IKAPI), 2017. Eko Riyadi, Hukum Hak Asasi Manusia, Perspektif Internasional, Regional, Regional dan Nasional, Depok, PT RajaGrafindo, 2017.

Buku Panduan Belajar KOAS, IImu Kedokteran Jiwa, Fakultas Kedokteran Universitas Udayana, Rumah Sakit Umum Pusat Sanglah, Departemen Psikiatri. 


\section{PERUNDANG-UNDANGAN}

Undang - Undang Republik Indonesia Nomer 39 Tahun 1999 Tentang Hak Asasi Manusia.

Undang - Undang Republik Indonesia Nomer 36 Tahun 2009 Tentang Kesehatan Undang - Undang Republik Indonesia Nomer 18 Tahun 2014 Tentang Kesehatan Jiwa.

\section{MEDIA MASSA ELEKTRONIK}

https://dosenpsikologi.com/perbedaan-gangguanjiwa-dan-gangguanmental https://ejournal.balitbanglam.go.id/index.php/kebijakan/article/download/90/30 https://www.juke.kedokteranunila.ac.id>article>download $>p d f$ 